\title{
The effect of the implementation of financial accounting standards on MSMEs
}

\author{
Hendra Raza ${ }^{a^{*}}$,Jumadil Saputra ${ }^{\mathrm{b}}$ and Zikri Muhammad ${ }^{\mathrm{b}}$
}

${ }^{a}$ Department of Accounting, Faculty of Economics and Business, Universitias Malikussaleh, Bukit Indah, Lhokseumawe, Indonesia ${ }^{b}$ Faculty of Business, Economic and Social Development, Universiti Malaysia Terengganu, 21030 Kuala Nerus, Terengganu, Malaysia

\section{H R O N I C L E}

\begin{tabular}{l}
\hline Article history: \\
Received March 18, 2021 \\
Received in revised format May \\
182021 \\
Accepted June 222021 \\
Available online \\
June 22 2021 \\
\hline Keywords: \\
Financial Accounting Standards \\
(FAS) \\
Perception \\
Education \\
Socialization \\
Micro, Small and Medium \\
Enterprises (MSMEs) \\
Aceh province \\
Indonesia context
\end{tabular}

\section{Introduction}

The global financial landscape has changed dramatically over the last two decades. These changes can be attributed to various factors, including drastic shifts in the corporate and political climates, increased global rivalry, the creation of more market-based economies, and rapid technology advancements (Helleiner, 2014). Simultaneously, the world's financial capitals have become more integrated. However, the body of accounting standards utilised does not guarantee that highquality financial information is delivered to the business (Opanyi, 2016). The management of a reporting firm is responsible for establishing and correctly applying generally accepted accounting standards, which is the foundation of an effective financial reporting structure. Auditors are tasked with determining whether the financial statements are fairly presented in conformity with certain accounting rules and issuing an opinion. Thus, high-quality accounting standards are essential for creating a high-quality global financial reporting structure (Sawani, 2009). There have been different accounting traditions

* Corresponding author.

E-mail address: hendra.raza@unimal.ac.id (H. Raza)

C 2022 Growing Science Ltd. All rights reserved. doi: $10.5267 /$ j.ac.2021.6.018

\begin{abstract}
Over the last two decades, the global financial landscape has changed dramatically, including the corporate and political climates, the creation of more market-based economies, and rapid technological advancements. Micro, Small, and Medium Enterprises (MSMEs) is one form of market-based economies created with the most significant business opportunities and very important socially and economically in developing countries for many reasons. However, MSMEs face significant difficulty related to financial reporting standards to evaluate the achievement of business activities. Most MSMEs use a simple form for financial reporting, such as by calculating the difference between inflow and outflow from their business activities. Also, numerous previous studies that focus on Financial Accounting Standards in Indonesia are still limited. Thus, the present study investigates the factors that influence the implementation of Financial Accounting Standards (FAS) of Micro, Small, and Medium Enterprises (MSMEs) in Aceh Province, Indonesia. This quantitative study uses cross-sectional data collected by distributing 200 questionnaires to MSMEs actors that spread North Aceh Regency, namely Lhokseumawe city and Bireuen regency. The data are analyzed using descriptive statistics (e.g., frequency, percentage, mean, standard deviation) and inferential statistic (multiple linear regression) analyses. The study indicated that Perception, Education, Socialization and Incentive factors had significant positive effects on implementing Financial Accounting Standards of Micro, Small, and Medium Enterprises (MSMEs) in Aceh Province, Indonesia. In conclusion, this study has successfully investigated the factors that influence the implementation of Financial Accounting Standards of Micro, Small, and Medium Enterprises (MSMEs) in Aceh Province.
\end{abstract}


worldwide in response to different needs of users for whom financial information is produced (Christiaens, Reyniers \& Rollé, 2010). Some countries, for example, have mainly been shaped by accounting standards by private creditors, and other countries are mostly influenced by the needs of tax authorities or central planners. Nowadays, Micro, Small, and Medium Enterprises (MSMEs) are one of the greatest business opportunities and very important socially and economically in developing countries for many reasons (Tambunan, 2019). Much evidence throughout the globe, particularly in poor/income countries, shows that micro-small businesses, especially in rural areas, play a crucial role in addressing poverty, inequality, and job creation obstacles (Stevenson, 2010). MSMEs are also an important source for low-skilled women and youth to find a job or business opportunity (Tambunan, 2011). Moreover, these businesses are a major growth engine for economic growth and the export of manufactured goods in many countries (Tambunan, 2006). In Indonesia, MSMEs are defined on the basis of the number of employees or labour (Indonesia Central Bureau of Statistics, 2020). Also, the MSMEs are effective solutions for the Indonesian government to overcome the unemployment issues. However, MSMEs face another significant difficulty, such as financial reporting standards to evaluate the achievement of business activities (Perera \& Chand 2015). Besides that, the MSMEs use a simple form for financial reporting, such as calculating the difference between inflow and outflow from their business activities.

Hence, MSMEs Accounting Standards were officially launched by the Indonesian government. However, due to the changes in MSMEs definition, the accounting standard is named Indonesian Accounting Standards for Non-Publicly Accountable Entities (IAS-NPAE) and explicitly created for MSMEs. Unfortunately, several MSMEs have not implemented their MSMEs accounting standards. Thus, the Indonesia Accountant Association, through Financial Accounting Standards Board, has approved the Exposure Draft Financial Accounting Standards (EDFAS) for Micro, Small and Medium Enterprises (MSMEs) effective starting January 1, 2018. The MSMEs financial statements only consist of balance sheets, income statements and notes to financial statements; the basis for measuring financial statement elements is only on a historical cost basis. In conjunction with the issue, the MSMEs actors must understand the Financial Accounting Standards of Micro, Small, and Medium Enterprises (MSMEs) to support their business activities. Further, previous studies that focus on Financial Accounting Standards in Indonesia are still limited. Thus, the present study aims to investigate the factors that influence the implementation of Financial Accounting Standards (FAS) of Micro, Small, and Medium Enterprises (MSMEs) in Aceh Province, Indonesia.

\section{Literature Review}

\subsection{Micro, Small and Medium Enterprises (MSMEs)}

Micro, Small and Medium Enterprises (MSMEs) are defined as micro-enterprises: 1-9 employees; small: 10-49 employees; and medium: 50-249 employees (Kushnir, Mirmulstein \& Ramalho, 2010). However, the local definition of MSMEs vary from country to country and is based not only on the number of employees but also on the inclusion of other variables such as turnaround and assets (Kiraka, Kobia \& Katwalo, 2015). MSMEs play an important role in the broader ecosystem of firms (Mehta, 2013). Start-ups and young firms, which are generally small or micro, are the primary source of net job creation in many countries and are the driving force of innovation and sustainability in the private sector (Mettler \& Williams, 2011). According to Stein, Goland \& Schiff (2010), there are about 365-445 million MSMEs in emerging markets: 25-30 million are formal SMEs, 55-70 million are formal micro, and 285-345 million are informal enterprises. In general, Hasanah \& Ratna Anggraini (2017) stated that SMEs in running their business with little capital, limited funding sources, the ability to obtain bank credit loans is relatively low due to incapacity to provide assurance, accounting, and others, the business operators of SMEs do not understand bookkeeping or accounting especially the financial statements and sector is less able to foster relationships with banks.

\subsection{Financial Accounting Standards (FAS) Implementation}

A set of principles, standards, and procedures that define financial accounting policies and practices is known as an accounting standard (Holthausen \& Watts, 2001). Accounting standards cover the entire financial picture of a company, including its assets, liabilities, revenue, expenses, and shareholders' equity (Benston, Bromwich \& Wagenhofer, 2006). However, the MSMEs only keep track of the money they received and spent, the goods they buy and sell, and the amount receivable or debt (Dedeh, Akbar \& Putra, 2020). A study conducted by Hasanah, Anggraini \& Purwohedi (2018) stated that MSMEs face challenges in preparing financial statements because of a lack of qualified human resources in accounting and time to prepare the report. Also, the MSMEs cost would be increased due to accounting staff salaries. Besides that, Adams \& Evans (2004) assess the implementation of Financial Accounting Standards by using four (4) indicators, including credibility, completeness, accountability and audit expectations gap.

\subsection{Micro, Small, and Medium Enterprises (MSMEs) Business Owner Perception}

Perception is the process of organising, identifying, and interpreting sensory data to represent and understand the information or environment presented (O'Dwyer, 2002). So then, McDougall (2015) defines perception as organising, interpreting the stimulus received by an individual and becoming something meaningful and integrated activity. It means 
that perception is the process of using something that is received through the five senses. So that everyone can choose, organise and translate information to create a meaningful world picture.

\subsection{Business Owner Education}

The educational requirements of a businessperson differ slightly from those of a business owner. An entrepreneur may work autonomously or outsource parts of their business upkeep to individuals with the right education/qualifications, whereas a business owner may oversee a fleet of employees. Notoatmodjo (2010) defined education as an effort of persuasion or learning to the community so that people want to take actions (practice) to maintain (overcome problems) and improve their health. Changes or actions for health care and improvement produced by health education are based on knowledge and awareness through the learning process. The behaviour is expected to be long-lasting and persist due to its awareness.

\subsection{Business Socialization}

The notion of socialisation is a process that helps community members learn and adapt to how the group lives and how the group thinks so that they can play a role and function in the group (Bühler, 1968). The meaning of socialisation in a broad sense is a process of interaction and learning carried out by a person from birth to the end of his life in community culture. Through the socialisation process, a person can understand and exercise their rights and obligations based on their respective status roles according to the culture of the community. In the Financial Accounting Standards of MSMEs, the income statement includes items, namely, revenue, financial expenses and tax expenses. An entity shall present the items and portions of items in the income statement when the presentation is relevant to understanding the entity's financial performance. The income statement includes all revenue and expenses recognised during the period unless Financial Accounting Standards of MSMEs required other matters. A study by Kusuma \& Lutfiany (2018) indicated that MSMEs socialisation and related factors had contributed as much as 57.5 percent in implementing Financial Accounting Standards (FAS) of MSMEs.

\subsection{Incentive Factors}

A study was conducted by Kusuma \& Lutfiany (2018) found that the incentive factor has a significant effect on the implementation of Financial Accounting Standards (FAS) of MSMEs, and it's the most dominant in influencing the implementation of Financial Accounting Standards (FAS) of MSMEs. Based on the relationship between perceptions (X1), an education level (X2), socialisation (X3) and Incentive factors (X4), the implementation of Financial Accounting Standards (FAS) of MSMEs (Y), the conceptual framework described as follows:

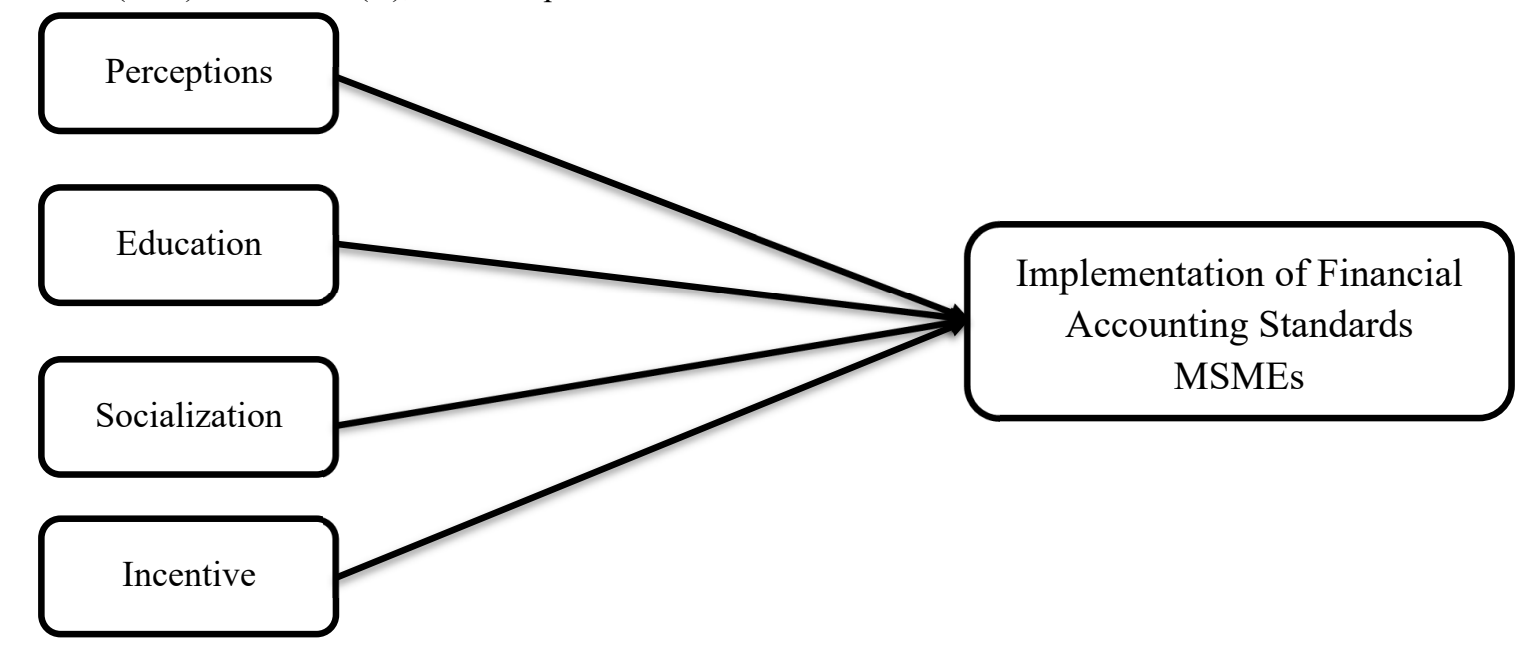

Fig. 1. Research Framework

In line with research background and review literature, this study proposes several hypotheses by the following:

$\mathbf{H}_{1}$ : Perceptions has a significant positive effect on the implementation of Financial Accounting Standards of MSMEs.

$\mathbf{H}_{2}$ :The education level has a significant positive effect on the implementation of Financial Accounting Standards of MSMEs.

$\mathbf{H}_{3}$ : Socialization has a significant positive effect on the implementation of Financial Accounting Standards of MSMEs.

$\mathbf{H}_{\mathbf{4}}$ :The incentive factor has a significant positive effect on the implementation of Financial Accounting Standards of MSMEs. 


\section{Materials and Methods}

This quantitative study uses cross-sectional data collected by distributing 200 questionnaires to MSMEs actors that spread North Aceh regency, Lhokseumawe city, and Bireuen regency. The population of this study were MSME entrepreneurs who carried out their business across North Aceh District is 3,660, Lhokseumawe City is 2,354 and Bireun District is 6,998 (Aceh Cooperative and SMEs Service, 2020). The sampling criteria are Micro, Small and Medium Enterprises in the district which are divided into Aceh Government and the status of business ownership. According to Arikunto (2010), the sample is a part or representative of the population to be studied. In this study, the determination of the number of samples refers to Giebenrath et al., (2003). In a quantitative study, when the population is too large, it is allowed to use a sample size between $100-200$. This study determined the number of samples as many as 200 respondents by using the purposive sampling method. The respondents were directly selected based on certain considerations, namely MSMEs that recorded financial reports each year.

In addition, this study involved four independent variables in determining its relationship to the implementation of Financial Accounting Standards of Micro, Small, and Medium Enterprises (MSMEs). The studied variables are perception, education, socialisation, and incentive factors measured using five (5) Likert scales (e.g., strongly disagree to strongly- agree). Further, this study determines the level of consistency and accuracy of the data collected from research instruments. Testing the quality of the research data can be done by testing the validity and reliability - the validity of instruments tested by using Pearson Correlation. According to Sugiono (2008), the items categorised as valid when the value of correlation are significant $(\mathrm{P}-$ Value $<0.05)$. For testing the measurement scale, this study used the Cronbach Alpha $(\alpha)$. In line with Nunnally (1994), the variables or constructs were classified as reliable when the value of Cronbach Alpha $(\alpha)$ was higher than 0.70 . The data analysed using descriptive statistics (e.g., frequency, percentage, mean, standard deviation) and inferential statistics (multiple linear regression) analyses.

\section{Results and Discussion}

\subsection{Results}

Before testing the proposed hypotheses, this study provides the results of the validity and reliability measurement scale. The validity of instruments is assessed by using a correlation coefficient between an item and its variable. This study uses a correlation coefficient (r) to identify whether the items are valid. The items were categorised as valid when the value of correlation between the item and its value is higher than 0.60 and significant at the level of 0.05 or $5 \%$. In addition, reliability tested using Cronbach Alpha. According to Hair et al. (2009), Cronbach Alpha's value should be equal to 0.60. Therefore, if the Cronbach alpha value is higher than 0.60 , we can conclude that the measurement scale used is reliable.

Table 1

The result of item validity and reliability of measurement instruments

\begin{tabular}{|c|c|c|c|c|}
\hline Variable(s) & Item & $r$-stat & Cronbach Alpha & Decision \\
\hline \multirow{6}{*}{ Perception } & $\mathrm{X} 1.1$ & 0.725 & \multirow{6}{*}{0.907} & \multirow{6}{*}{ Reliable } \\
\hline & $\mathrm{X} 1.2$ & 0.798 & & \\
\hline & $\mathrm{X} 1.3$ & 0.683 & & \\
\hline & $\mathrm{X} 1.4$ & 0.674 & & \\
\hline & $\mathrm{X} 1.5$ & 0.768 & & \\
\hline & $\mathrm{X} 1.6$ & 0.769 & & \\
\hline \multirow{4}{*}{ Education } & $\mathrm{X} 2.1$ & 0.779 & \multirow{4}{*}{0.913} & \multirow{4}{*}{ Reliable } \\
\hline & $\mathrm{X} 2.2$ & 0.783 & & \\
\hline & $\mathrm{X} 2.3$ & 0.772 & & \\
\hline & $\mathrm{X} 2.4$ & 0.782 & & \\
\hline \multirow{6}{*}{ Socialization } & X3.1 & 0.658 & \multirow{6}{*}{0.906} & \multirow{6}{*}{ Reliable } \\
\hline & X3.2 & 0.770 & & \\
\hline & X3.3 & 0.727 & & \\
\hline & X3.4 & 0.697 & & \\
\hline & X3.5 & 0.640 & & \\
\hline & $\mathrm{X} 3.6$ & 0.641 & & \\
\hline \multirow{4}{*}{ Incentive Factors } & $\mathrm{X} 4.1$ & 0.756 & \multirow{4}{*}{0.906} & \multirow{4}{*}{ Reliable } \\
\hline & $\mathrm{X} 4.2$ & 0.863 & & \\
\hline & $\mathrm{X} 4.3$ & 0.886 & & \\
\hline & $\mathrm{X} 4.4$ & 0.856 & & \\
\hline \multirow{6}{*}{ Financial Accounting Standards } & Y.1 & 0.843 & \multirow{6}{*}{0.912} & \multirow{6}{*}{ Reliable } \\
\hline & Y.2 & 0.886 & & \\
\hline & Y.3 & 0.826 & & \\
\hline & Y.4 & 0.871 & & \\
\hline & Y.5 & 0.859 & & \\
\hline & Y.6 & 0.807 & & \\
\hline
\end{tabular}


Table 1 displays the result of item validity and reliability of measurement instruments. This study involved several variables, namely Perception, Education, Socialization, Incentive Factors as the independent variable and Financial Accounting Standards as a dependent variable. Referring to $r$-stat, this study found that the minimum value of r-count is 0.640 , and the maximum value is 0.886 . Thus, we can conclude that the items were valid. In addition, this study uses Cronbach Alpha in measuring the reliability of the measurement scale. The analysis result found that the minimum value of Cronbach Alpha is 0.907 (Perception), and the maximum value is 0.913 . Therefore, it means that the measurement scales are reliable.

After conducting the item validity and reliability, this study tests the proposed hypotheses using multiple linear regression analyses. Besides that, this study first reported the result of the coefficient determination. The coefficient of determination (R-Square) identifies the extent to which the independent variables explained its relationship to the dependent variable. $\mathrm{R}$ Square value is higher than 0 (zero) and less than 1 (one). According to Ghozali (2012), when the results showed the R square value is close to 1 , the independent variables almost provide all the desired information on the predictions of the dependent variable. In other words, the independent variables can explain their relationship to the dependent variable. Hence, the result of the coefficient determination, as seen in Table 2.

Of these, the result of the $\mathrm{R}$ Square value is 0.656 . It means three independent variables explained its relationship to Implementation of Financial Accounting Standards is 0.656 or $65.6 \%$. Meanwhile, the remaining $34.4 \%$ is explained by other variables not included in this study. Also, the result of the F stat is 95.963 and significant at the level 1 percent. It indicates that the independent variables (perception, level of education, socialisation and incentive factors) have simultaneously influenced the implementation of Financial Accounting Standards of MSMEs. The result of hypotheses testing, as seen in Table 2 below:

Table 2

The result of hypotheses testing

\begin{tabular}{|c|c|c|c|c|c|c|}
\hline \multirow{2}{*}{ Variable(s) } & \multirow{2}{*}{ B } & \multirow{2}{*}{ Std. Error } & \multirow{2}{*}{$\mathrm{t}$} & \multirow{2}{*}{ Sig. } & \multicolumn{2}{|c|}{ Collinearity Statistics } \\
\hline & & & & & Tolerance & VIF \\
\hline (Constant) & -9.909 & 1.855 & -5.341 & 0.000 & & \\
\hline Perception & 0.323 & 0.071 & 4.549 & 0.000 & 0.620 & 1.614 \\
\hline Level Education & 0.225 & 0.091 & 2.477 & 0.014 & 0.899 & 1.112 \\
\hline Socialization & 0.309 & 0.080 & 3.875 & 0.000 & 0.590 & 1.695 \\
\hline Incentive Factors & 0.840 & 0.084 & 10.062 & 0.000 & 0.700 & 1.428 \\
\hline $\mathrm{R}$ & \multicolumn{2}{|c|}{$0.814^{\mathrm{a}}$} & \multicolumn{2}{|r|}{ Adj. R Square } & \multicolumn{2}{|c|}{0.656} \\
\hline R Square & \multicolumn{2}{|c|}{0.663} & & Std. Error of the Estimate & \multicolumn{2}{|c|}{3.221} \\
\hline $\mathrm{F}$ & \multicolumn{2}{|c|}{95.963} & & \multirow[t]{2}{*}{ Durbin-Watson } & \multirow{2}{*}{\multicolumn{2}{|c|}{1.722}} \\
\hline Sig. & & & & & & \\
\hline
\end{tabular}

Table 2 shows the result of hypothesis testing. The analysis indicated that Perception, Level Education, Socialization, and Incentive Factors have a significant positive effect on Financial Accounting Standards. The value of the regression coefficient for owner perception is 0.323 , std. error is equal to $0.071, \mathrm{t}$-stat is 4.549 and Sig. 0.000 or 1 percent. It means that assuming an increase of 1 percent in owner perception (other factors are unchanged), then implementation of Financial Accounting Standards would increase as much as 32.3 percent. Also, Level Education coefficient regression is 0.225 , std error equal to 0.091 , t-stat is 2.477 and Sig. 0.014 or 1 percent. It indicated that assuming an increase of 1 percent in owner perception (other factors are unchanged), implementing Financial Accounting Standards would increase 22.5 percent. For socialisation, the regression coefficient value is 0.309 , std error equal to 0.080 , $t$-stat is 3.875 and Sig. 0.000 or 1 percent. It means that assuming an increase of 1 percent in owner perception (other factors are unchanged), then implementing Financial Accounting Standards would increase 30.9 percent. In addition, the value of regression coefficient for Incentive Factors is 0.840 , std error equal to 0.084 , $t$-stat is 10.062 and Sig. 0.000 or 1 percent. It means that assuming an increase of 1 percent in owner perception (other factors are unchanged), then implementing Financial Accounting Standards would increase 84 percent. In conclusion, the proposed hypotheses, i.e., H1, H2, H3 and H4, are supported (see Table 3).

Table 3

Summary of Hypotheses Decision

\begin{tabular}{clc}
\hline Hypothesis & & Statement of Hypotheses \\
\hline H1 & Perception has a significant positive effect on the implementation of Financial Accounting Standards of MSMEs. \\
H2 & The education level has a significant positive effect on the implementation of Financial Accounting Standards of SMEs & Supported \\
H3 & Socialisation has a significant positive effect on the implementation of Financial Accounting Standards of MSMEs & Supported \\
H4 & The incentive factor has a significant positive effect on the implementation of Financial Accounting Standards of SMEs & Supported \\
\hline
\end{tabular}

\subsection{Discussion}

This study discusses the result of the research and elaborates its findings with similar and dissimilar research outcomes. The result of this study is that owner perception has a significant positive effect on the implementation of Financial Accounting 
Standards (FAS) of MSMEs. A similar finding reported by Janrosl (2018) found that owner perception is an important variable in explaining FAS implementation and has a significant effect on the FAS of MSMEs. Further, this study found that level of education has a significant positive effect on the FAS of MSMEs. The result of this study contrasts with Febriyanti \& Wardhani (2018), they found that level of education does not significantly affect the implementation of Financial Accounting Standards (FAS) of MSMEs. They added that the education level of MSME actors does not guarantee the implementation of Financial Accounting Standards (FAS) of MSMEs will be higher.

Socialisation has a significant positive effect on the implementation of Financial Accounting Standards (FAS) of MSMEs. The result of this study supported by Kusuma \& Lutfiany (2018), which found the socialisation of Financial Accounting Standards (FAS) of MSMEs has a positive effect on the implementation of Financial Accounting Standards (FAS) of MSMEs in Bogor City, Indonesia. Also, the incentive factor has a significant positive effect on the implementation of Financial Accounting Standards (FAS) of MSMEs. A similar study found that Kusuma \& Lutfiany (2018) stated that the incentive factor has a significant effect on the implementation of Financial Accounting Standards (FAS) of MSMEs, and it's the most dominant in influencing the implementation of Financial Accounting Standards (FAS) of MSMEs.

\section{Conclusion}

In conclusion, this study has successfully investigated the factors that influence the implementation of Financial Accounting Standards of Micro, Small, and Medium Enterprises (MSMEs). This study found that Business Owner Perception, Education, Socialization and Incentive factors significantly affect the implementation of Financial Accounting Standards of Micro, Small, and Medium Enterprises (MSMEs) in Aceh Province, Indonesia. The research finding provides the guidelines for the Financial Accounting Standards Board to identify the needs and importance of bookkeeping using accounting standards. Also, this study provides the direction and explanation about the relationship between financial accounting standards and business performance.

\section{Acknowledgement}

We would like to thank Universiti Malaysia Terengganu for supporting this research publication and this excellent collaboration work with Universitas Malikussaleh.

\section{References}

Adams, C. A., \& Evans, R. (2004). Accountability, completeness, credibility and the audit expectations gap. Journal of Corporate Citizenship, 14, 97-115.

Arikunto, S. (2010). Research Methodology. Rineka Cipta.

Benston, G. J., Bromwich, M., \& Wagenhofer, A. (2006). Principles-versus rules-based accounting standards: the FASB's standard setting strategy. Abacus, 42(2), 165-188.

Bühler, C. (1968). The course of human life as a psychological problem. Human Development, 184-200.

Christiaens, J., Reyniers, B., \& Rollé, C. (2010). Impact of IPSAS on reforming governmental financial information systems: a comparative study. International Review of Administrative Sciences, 76(3), 537-554.

Dedeh, D., Akbar, D. S., \& Putra, R. A. (2020). The Application of Simple Accounting Format In Tradisional Shop. Sosio E-Kons, 11(3), 195-203.

Giebenrath, J. L., Burns, J. J., Hockensmith, T. A., Hession, P. J., Brewer, J., McDonald, D., \& TSD, N. O. (2003). Extending the Team Learning Methodology to Coalition Training. Proceedings of 2003 Industry/Interservice Training Systems Conference.

Hasanah, N., \& Ratna Anggraini, Z. R. (2017). Accounting Standards Perceptions in Small Medium Enterpricess: Case Study in Indonesia. Advanced Science Letters, 23(11), 10753-10756.

Hasanah, N., Anggraini, R., \& Purwohedi, U. (2018). Accounting Standards: The Lessons from Small and Medium Enterprises. Academy of Accounting and Financial Studies Journal, 22(5), 1-10.

Helleiner, E. (2014). The status quo crisis: Global financial governance after the 2008 meltdown. Oxford University Press.

Holthausen, R. W., \& Watts, R. L. (2001). The relevance of the value-relevance literature for financial accounting standard setting. Journal of Accounting and Economics, 31(1-3), 3-75.

Janrosl, V. S. E. (2018). Analysis Of Perceptions Of MSMEs Performers and Financial Accounting Standards (FAS) Socialization On The Implementation Of Financial Reports Based On FAS of MSMEs. Jurnal Akuntansi Keuangan Dan Bisnis, 11(2), 97-105.

Kiraka, R., Kobia, M., \& Katwalo, A. M. (2015). Micro, small and medium enterprise growth and innovation in Kenya: A case study on the Women Enterprise Fund.

Kushnir, K., Mirmulstein, M. L., \& Ramalho, R. (2010). Micro, small, and medium enterprises around the world: how many are there, and what affects the count. In MSME Country Indicators.

Kusuma, I.C. \& Lutfiany, V. (2018). Perception of MSMEs in Understanding Financial Accounting Standards of MSMEs. Universitas Djuanda: Bogor.

McDougall, W. (2015). An introduction to social psychology. Psychology Press. 
Mehta, S. (2013). Towards creating a sustainable design eco-system for MSMEs: A design clinic approach. 2013 IEEE Tsinghua International Design Management Symposium, 230-235.

Mettler, A., \& Williams, A. D. (2011). The rise of the micro-multinational: How freelancers and technology-savvy startups are driving growth, jobs and innovation. Lisbon Council Policy Brief, 5(3), 1-28.

Notoatmodjo, S. (2010). Health behavioral science. Penerbit Rineka Cipta.

O'Dwyer, B. (2002). Managerial perceptions of corporate social disclosure: An Irish story. Accounting, Auditing \& Accountability Journal.

Opanyi, R. O. (2016). The effect of adoption of international public sector accounting standards on quality of financial reports in public sector in Kenya. European Scientific Journal, 12(28), 161-187.

Perera, D., \& Chand, P. (2015). Issues in the adoption of international financial reporting standards (IFRS) for small and medium-sized enterprises (SMES). Advances in Accounting, 31(1), 165-178.

Sawani, A. (2009). The changing accounting environment: international accounting standards and US implementation. Journal of Finance and Accountancy, 1, 1.

Stein, P., Goland, T., \& Schiff, R. (2010). Two trillion and counting. International Finance Corporation and McKinsey \& Company.

Stevenson, L. (2010). Private sector and enterprise development: fostering growth in the Middle East and North Africa. IDRC.

Tambunan, T. (2006). Micro, small and medium enterprises and economic growth. Center for Industry and SME Studies, Working Paper Series, 4.

Tambunan, T. (2019). Recent evidence of the development of micro, small and medium enterprises in Indonesia. Journal of Global Entrepreneurship Research, 9(1), 1-15.

Tambunan, T. T. (2011). Development of micro, small and medium enterprises and their constraints: A story from Indonesia. Gadjah Mada International Journal of Business, 13(1), 21-43. 
(C) 2022 by the authors; licensee Growing Science, Canada. This is an open access article distributed under the terms and conditions of the Creative Commons Attribution (CC-BY) license (http://creativecommons.org/licenses/by/4.0/). 